\title{
Problems and Prospects of the Forest Industry Development in Russia: a case study of Baikal region
}

\author{
$D$ Dayneko ${ }^{1, *}, A$ Dayneko $^{2}$, and $V$ Dayneko $^{2}$ \\ ${ }^{1}$ Irkutsk Scientific Centre SB RAS, Lermontov Street, 134-117 Irkutsk 664033, Russian Federation \\ ${ }^{2}$ Irkutsk National Research Technical University, 83 Lermontov Street, Irkutsk 664074, Russian Federation
}

\begin{abstract}
The Forest industry is an important part of the Russian economy, so its condition has a great influence on the Russian economy in general and on various aspects of life, from the production of raw materials for various industries (such as construction, agriculture, furniture production, etc.), ending the recreational role of forests in people's lives. In this paper the major current problems and the future of the Forest industry development in Russia are discussed. The systematization of the main problems in the Forest industry for its development in Baikal region is presented. These problems include the following: production and technological, natural and environmental, institutional and organizational, and problems of the forest protection. The innovative development issues in the Forest industry have been discussed. The program of innovative and institutional transformations of the Forest industry is presented.The implementation of the Forest innovation system is suggested for sustainable Forest industry management and is based on expert opinions.
\end{abstract}

\section{Introduction}

Russia is considered the world's largest forest country. Forests occupy $70 \%$ of its territory and are one of the main competitive advantages of the country. The country accounts for about $20.5 \%$ of the world's total forest area and half of coniferous forests. Most of the forest areas (29\%) are occupied by small-leaved and mixed forests that have grown on the site of old cuttings, hares, and agricultural land, as well as Northern and mountain woodlands. A slightly smaller area $(21 \%)$ is covered by larch forests. The coniferous forests cover approximately $19 \%$ of the forest land (with $11 \%$ of spruce, cedar and fir forests and only $8 \%$ of pine forests). The biggest rarity is broad-leaved woodlands. Their share is only $3 \%$ [2].

The total land area of the forest fund exceeds 1.1 billion hectares, which is $1 / 4$ of the world's wood reserves. Wood reserves in Russian forests are estimated to be about 75 billion $\mathrm{m} 3$. If we make a generalization, each Russian has ten times more forests than an American, and 35 times more than the average European. More than $20 \%$ of logs and lumber products are exported from Russia.

\subsection{The role of the Russian Forests}

The economic importance of forests in meeting the demand for wood is well known. However, along with the important role of forests in the socio-economic development of society, the ecological significance of forests is of great relevance. The ecological resource of forests implies regulatory functions (water and heat regimes of the earth's surface, water protection and water regulation functions); formation and preservation of soil cover; regulation and conservation of biodiversity; climate and weather changes; global carbon cycle; sanitary and hygienic, balneological and recreational roles.

The ecological value of forests is not limited to the territory of the State where they mature. Russian forests have a planetary significance and play an important role in global processes of environmental regulation and prevention of negative climate changes. Forests sequester a large share of the world's carbon dioxide emissions, For example, forests of Irkutsk province account for up to $1 / 3$ of the net carbon deposition of all the world's forests [2].

Another global role of the forest is photocatalytic transformation, carbon dioxide sequestration, and oxygen release. Thus, according to approximate calculations, the forests of the Irkutsk province only produce more than 72 billion $\mathrm{m} 3$ of oxygen annually [9]. In addition, the forests of the region growing in the catchment area of the lake Baikal and along the river banks play the water protection role, provide regulation and filtration of waste water and a constant water level. Forests that grow in mountainous areas protect weak soils on the slopes from flushing, weathering, snow avalanches and mudslides too.

It is worth noting the sanitary and hygienic significance and protective function of forests from dust, soot, and noise. Forest plantations protect crops and gardens from cold winds and improve the climate. Forests largely neutralize the effects of harmful

\footnotetext{
* Corresponding author: ddayneko@,oresp.irk.ru
} 
emissions from industrial enterprises. It is known that staying in the forest has a beneficial effect on human health and creativity. Given the diverse significance of forests, they should be considered not only natural, but also cultural heritage of the country.

\subsection{Russian Forest industry today}

Russian forest resources were a trigger for the creation of many branches of the national economy. Today, Russian forest complex is represented by the following industries:

1. Forestry (leskhoz) is intended for reproduction of the used resources and utilities (services) of forests, their protection from fires, protection from pests and diseases, various kinds of negative natural and anthropogenic impacts, ensuring the needs of society in forest products, preserving and improving the natural environment, resource and environmental potential, biodiversity for current and future generations.

2. Lumber industry complex (LIC):

1) Logging industry (LI), which priority tasks include harvesting and export of different types of wood;

2) Sawmill and Woodprocessing industry (SWPI), directly engaged in the production of lumber, fiberboard, hardboard, MDF, chipboard, OSB, plywood and other products;

3) Pulp and paper industry (PPI), production primarily of such products and materials as pulp, paper, newspaper, cardboard, paper bags, etc. PPI is a key and strategically important industry;

4) Forest chemical industry based on chemical processing of wood. It includes: dry distillation of wood, carbonation and various types of rosin-turpentine production.

Industries such as the agro-industrial complex (AIC) and the pharmaceutical industry are linked to the forage, food and medicinal resources of the forest. The importance of the Forest industry for all segments of the population is due to the social, protective and cultural benefits (services) of the Forest industry. The economy of the Forest industry develops its economic relations with a wide range of stakeholders, including producers, consumers and the population in general.

The main user of wood is the Wood Processing industry. The Russian Federation exports the following types of lumber products: roundwood, lumber, fuel wood, sleepers, chipboard and fiberboard, wood, paper and cardboard containers, pulp, paper, cardboard, wallpaper, paper hygiene products, paper and cardboard labels, etc.

\section{Problems and Prospects of the Russian Forest Industry}

Now let's study the problems and dynamics of the development of the Russian forest complex. Haphazard actions in forest management have led to the destruction of most of the forests in Western Europe and in central regions of Russia. As a result of excessive use of natural resources, there is a threat of destruction of the existing ecosystem, climate and water balance degradation, and from the economic point of view, the strategic potential of countries worsening. Forest conservation is the condition required to contain the ecological crisis on Earth. Forest as an exhausted but renewable resource is in the sphere of close attention of ecologists and economists. In the era of globalization of commodity and raw materials markets, when most of the forests in the United States and Europe are undergoing conservation and preservation, the sustainable environmental management practices are especially relevant for Russia and its regions, such as the Irkutsk province, which is the first among the country's logging regions.

The problem of nature degradation is related to the anthropogenic impact on forests. First, direct impact (deforestation, forest fires, construction of facilities, tourism, atmospheric emissions). Secondly, indirect, when the living conditions change as a result of air and water pollution, the use of mineral fertilizers and pesticides, which leads to changes in the plants composition). In addition, radioactive contamination is becoming a new factor in forests and vegetation degradation.

Currently, the complexity of forests management and reforestation is due to specific factors. First of all, a long period of forest cultivation. The age of mature largesized valuable trees is at least 70 years. It is necessary to observe the proportionality of forest use to the scale and timing of its reproduction. Compliance with the principle of "continuous, non-destructive use of forests" (CUUF) is stated in the Forest code [4] and is the main postulate of the organization of sustainable forest management [6].

Another specific factor is the multi-purpose use of the forests. Russian forests and the land they occupy perform various functions, ensuring the reproduction of resources, commodity and non-commodity products. Using the forest as a source of wood, it is necessary to take into account other previously noted useful functions: protective, recreational, and other. The multipurpose forest management approach is the basis for sustainable biodiversity conservation and is consistent with international agreements on forests.

The organization of forestry on the principles of sustainable and multi-purpose forest management can be effective in the form of multi-level forest management. In this case, forest resources and products are divided into two groups: market resources, which have the market value, and public goods, which are indivisible between individual consumers.

\subsection{The specific problems of the Forest industry in Russia}

Let's highlight the specific problems of the Russian Forest industry. They can be subdivided into: 1) industrial and technological; 2) nature related and ecological; 3) institutional and organizational; 4) related to problems of forest protection [11]. 


\subsubsection{Production and technological problems}

These include:

- Imperfection of logging and reforestation technologies, low efficiency of the forest reproduction system, due to the significant excess of logging areas over reforestation. In some areas, forests lose their climate and water-regulating significance. There is a decrease in the share of coniferous forests and an increase in the share of soft-leaved plantations due to improper exploitation of forests. Poor reforestation is explained by the termination of self-seeding, destruction of undergrowth, soils degradation during logging and transportation of wood.

- Outdated processing technologies and inefficient use of wood. Rational use of wood while harvesting implies the full utilization of the resource. However, in practice, losses are at least $30 \%$ of the total wood output. They occur due to incomplete logging, under-logging, and abandoned trees. The applied cutting technologies lead to the destruction of undergrowth. In addition, bark ( $10 \%$ of the volume of wood), twigs (12\%), stumps (8\%) are lost when harvesting wood. The use of outdated wood processing technologies leads to the loss of wood and, as a result, to the high cost of forest production.

- The unavailability of huge forest areas for intensive development of the Forest industry due to the lack or absence of roads, the construction of which for the maintenance and operation of forests in existing conditions is highly costly for existing and potential forest users.

- The lack of capacity for deep processing of wood. In order to ensure more rational use of natural resources and generate greater export revenues, it is necessary to develop capacities for deeper processing of raw materials. For many decades, Russia has been exporting mainly roundwood (more than 15 million m3 annually), which accounts for about $20 \%$ of the business timber harvest. In the second place is cellulose. Lumber, paper, cardboard and plywood and other wood processed products are sold in smaller volumes.

- Low technical level of production and noncompliance with international standards. The most urgent task of forest management is to create a national system of forest certification necessary for effective supply and management of forests. The border for noncertified forest is almost closed today. Russian lumber producers have limited access to world markets.

- High degree of depreciation of the main industrial and production assets. The depreciation of main technological equipment in the Forest industry in some regions, such as, for example, in Irkutsk province reaches $80 \%$. Thus, in the most capital-intensive Pulp and paper industry, most of the equipment was physically and morally outdated. Productivity at the best enterprises is $30-40 \%$ of the Scandinavian level, and at others about $10 \%$. The problem is further complicated by the lack of competitive domestic equipment, insufficient attraction of private investments, including foreign investment too.

\subsubsection{Natural and ecological problems}

These include:

- The diseases and harmful insects impact on forests for which it is assumed to use physical, mechanical, chemical and biological methods of control, and forestry measures.

- Forest fires are one of the most serious problems of Russian forests [2]. The main reason for their occurrence is the careless handling of fire by individuals.

- Ecological aspects of forest management by large lumber companies in Russia. Today, we have environmental requirements for forest exploitation and priority measures for forestry established, and forests requiring restoration have been identified, including at the expense of state subsidies. Forest users are obliged to preserve the flora and fauna. The contradiction between the interests of economic development at the expense of forest raw materials and ecology based on forest conservation is one of the main problems of environmental protection. The administrative-legal influence, restrictions, administrative and criminal penalties are the tools for solving this problem for many years. The main lever of administrative and legal influence and economic mechanism here are the institutions that have been operating for a long time and are being newly created in the Forest industry [6].

- Depletion of wood reserves in areas where existing forest enterprises are located.

\subsubsection{Institutional and organizational problems}

These are those that affect the effectiveness of the use of resources. The existing institutional structure of the Forest industry did not allow the forest business to function effectively for many years and contribute to the sustainable socio-economic development of territories. Over the years of reforms, the forest management system has undergone significant transformations. This has happened due to issues of ownership, organizational restructuring, and changes in forest legislation. The institutional structure and institutional changes in the forest sector are closely linked to forest policies that regulate the economic, social and environmental consequences of forest management, including ownership and management issues., There is a need for the system of national and regional forest policy measures to encourage effective entrepreneurship in the forest sector, which requires a thorough institutional analysis.

The defining institutions in the use of forest resources are: the ownership institution; investment institutions (banks, insurance companies, funds, etc.); the legal framework for forest management (laws, regulations, decrees, projects, standards and regulations); the taxation system, including rules and regulations that determine how the State collects the part of the forest income; the organizational structure of the industry as a whole and the organizational structure of individual enterprises; information support for the industry and organizations; institutions that ensure the development and implementation of regulatory documents; 
institutions that provide professional training and education of personnel; informal institutions that support manufacturing enterprises.

The main institutional problems of the Russian forest sector are related to both the legitimacy of forest resource consumption and non-compliance with environmental standards, delays in their adoption and implementation. There are significant contradictions in the forest legislation and there are conflicts with other laws of the Russian Federation. This leaves open the question of allocation of rights to forest management. A number of sources also note the complexity of tax policies that do not promote economic activity or new investment; the problem of forest payments return back to the forest sector; the presence of corruption schemes that become a serious obstacle to the development of business activity in the forest sector; the closeness or lack of financial information and statistics.

However, the imperfect Federal legislation is the obstacle to effective use of forests. The entities of the Russian Federation had received powers in the field of forest management, as the new forest legislation was introduced. In particular, they are entrusted with forestry planning, providing forest lots within the borders of the forest fund lands, organizing the protection, forests conservation and reproduction of, and implementation of the State forest control and supervision.

However, the issues of solving the problems of lack of raw materials, reduced investment, technical backwardness, shortage of highly qualified personnel, poor use of technologies for deep processing of wood and others are still present. The effective development of the industry is possible only on the innovative basis, which requires, first of all, the restructuring of institutional relations.

The list of problems presented shows that inefficient use of forests is primarily due to ineffective institutional relations in the industry. First of all, this relates to inefficient ownership rights to forest resources.

According to the theory of ownership rights, effective can be called such property rights, in which the owner makes the best use of his property of all possible ways of use [41]. The most effective use of property rights is provided, on the one hand, by the properties of the property rights themselves, on the other by external incentives.

The properties of effective property rights are the following: 1) clarity and unambiguity, i.e. clarity (transparency) of the property rights, it is when it is clear which object belongs to whom (this also includes the specification of property rights, i.e. an accurate description of property rights in relation to the properties of the object of property rights);2) enforceability or realizability, which is provided by the State system of property rights protection and enforcement, customs, criminal methods, contracts; 3 ) exchangeability, i.e. the ability of the owner to sell, gift, i.e. there should be a market for property rights.

External incentives for effective use of property rights are provided by the following: 1) the specification of property rights, which is provided by the owner's protection from violation of property rights, including violations by the State; 2) reliable protection of property rights of the owner's assets. Among certain property rights, the most important are the following:

- the ownership right, i.e. physical control over property and assignment of rents;

- the right of disposal and management, i.e. the right to make decisions about who can use the resource and how;

- the right to use, i.e. the right to personal use of a resource.

In fact, until the ratification of the Forest code, there was no institution of ownership for forest resources in Russia. The first legal document that became the basis of the formal institution of ownership of forest resources was the Forest code of the Russian Federation, introduced back in 1997. In the Forest code the right of possession was reserved for Russian Federation for the first time, i.e. actually the Federal form of forest ownership was established and the right of control was transferred to the constituent entities of the Russian Federation, the right of use was granted to forest enterprises and other commercial structures as the rent. It is the Forest code that had become a tool for specifying ownership rights to forest resources. According to the theorem of R. Coase, the right of ownership is fully defined when each right has its own exclusive owner. This right is currently legislated to reduce the risk of alienation of property.

Thus, the scheme of specification of property rights in the Forest code was outlined and the entities for the laws were defined. However, entitlements were not transparently defined among entities. The right of management was divided among the Russian Federation and its entities. The interests of the parties involved clashed and came into conflict. Many business people wanted to get access to forest resources, and after getting forest tickets, they wanted to make the maximum profit without taking into account public interests and the environmental issues.

The question of whether it was the right decision to refuse the forests privatization and solve all production issues exclusively on terms on the rent remains open too. In any case, attempts to form a model of private forest ownership in Russian society proved to be inadequate to the models in developed countries. The attempt to privatize Russian forests became an example of a failed economic experiment in Russia with negative social and environmental consequences. The readiness of the Russian society for private ownership of forests has not been defined, nor have the terms and conditions for social responsibility of forest businesses been defined.

The analysis of the transformation processes happening in the country confirms that with maintaining of the State ownership for forest resources, there may be a conflict related to the "right to manage" forest resources, which is caused by the redistribution of this right in favor of the Russian Federation or regions as entities of the Russian Federation. Relations among entities were formed empirically during 2005-2013, when there was a significant tendency to centralize Federal power in the forest sector. Regions have lost the ability to participate independently in joint management 
in relation to the management of the forest fund as the State property. This initiative provoked a strong negative reaction locally. The powers that belonged to the entities of the Russian Federation in accordance with the Forest code were returned and expanded by Federal law no. 199 dated December 31, 2005. It included almost all the functions of State and economic management of the forest fund. Subsequently, the authorities in the region tried to consolidate and expand their rights, sought to tighten the conditions for forest use, and proposed to cancel auctions and replace them with competitions. The forest business itself opposed such changes, considering them as an infringement on the freedom of economic relations [1].

The question of which entities will conduct forest business or implement its individual activities is still open and depends on the forms of forest relations adopted at each stage, taking into account specific conditions. However, knowing that the Russian forests are federally owned, the Federal state authority is responsible for conducting forest activities, taking into account the legally accepted requirements too. So, it delegates the functions of State forest management to the authorized bodies in all executive power blocks.

Today, we can note that the State's influence on the development of the forest sector of the economy is generally not effective enough. The State can and should intervene in the distribution of income through the taxation system, regulation of prices and wages, and can influence the balance of supply and demand through the distribution of income, creating conditions for the reproduction and renewal of forest goods necessary for society. The problems of the Forest industry are related not only to the operation of market mechanisms, but also to measures of the State regulation that ensure the balance between economic development and protection of the environment.

\subsubsection{The forest protection problems}

There is a number of shortcomings in this area which should be noted. The first official nature protection document concerning forests appeared on April 4, 1888, when the tsarist government, influenced by public opinion, issued the Forest Protection law that regulated forest management in forests that perform primarily nature protection functions, and restricted certain rights of forest owners.

The modern Federal law "About specially protected natural territories", signed by the President of the Russian Federation [5], distinguishes the following categories of specially protected natural territories: State nature reserves; national parks; natural parks; State nature reserves; natural monuments; dendrological parks, and botanical gardens; health-improving areas and resorts. In addition, the government of the Russian Federation, executive authorities of constituent entities of the Russian Federation, and local governments may establish other categories of specially protected natural territories (for example, green zones, urban forests, urban parks, protected coastlines, protected landscapes, biological stations, micro-reserves, and others).

Today, forest management, as well as Forest legislation itself, is still complex and confusing in Russia. This problem is faced by forestry workers themselves too when deciding on the application of certain forest regulations. Furthermore, certain provisions of forest legislation and regulations conflict with land, water and environmental legislation often too. According to the industry employees themselves, the draft of the new Forest code of the Russian Federation did not avoid these shortcomings. The transition from a centrally planned to the market economy without a wellfounded program worsened the existing nature of the structure and location of the Forest industry and forestry, causing in the late 1990s and early 2000s unprecedented for the history of Russia collapse of production in the Forest industry.

Thus, innovative changes in the Forest industry that can increase the efficiency and productivity of the industry are not possible and must begin with institutional changes in ownership and in other institutional relationships. The primary condition for the Forest industry transformation on the innovative basis is the formation of the innovative system for the industry. Now we will study the advanced experience in the field of forest management and development of the Forest industry in Russia to analyze the concept and composition of the innovative system of the Forest industry.

Currently, the complexity of forest management and reforestation are due to specific factors. First of all, this is the long period of forest cultivation. The age of largesized valuable trees is at least 70 years. It is necessary to follow the proportionality of forest use to the scale and timing of its reproduction. The compliance with the principle of "continuous, sustainable forest management" (CSFM) is enshrined in the Forest code [10] and is the main postulate of the sustainable forest management implementation [6].

Another specific factor is the multi-purpose of the forests. Russian forests and the lands which they occupy perform various functions, ensuring the reproduction of resources, commodity and non-commodity products. While using forests as a source of wood, it is necessary to take into account its other benefits noted earlier: protective, recreational, and other. The multi-purpose forest management approach is the basis for sustainable biodiversity conservation, and is consistent with international agreements on forests.

\subsection{Prospects of the Forest industry}

The analysis of the current situtation and problems in the Russian Forest industry, allows us to identify the negative impact of industrial expansion on the state of forests. The modern economic development requires a new paradigm for the development of human relations with the environment, which sets the vector of sustainable forest management. 


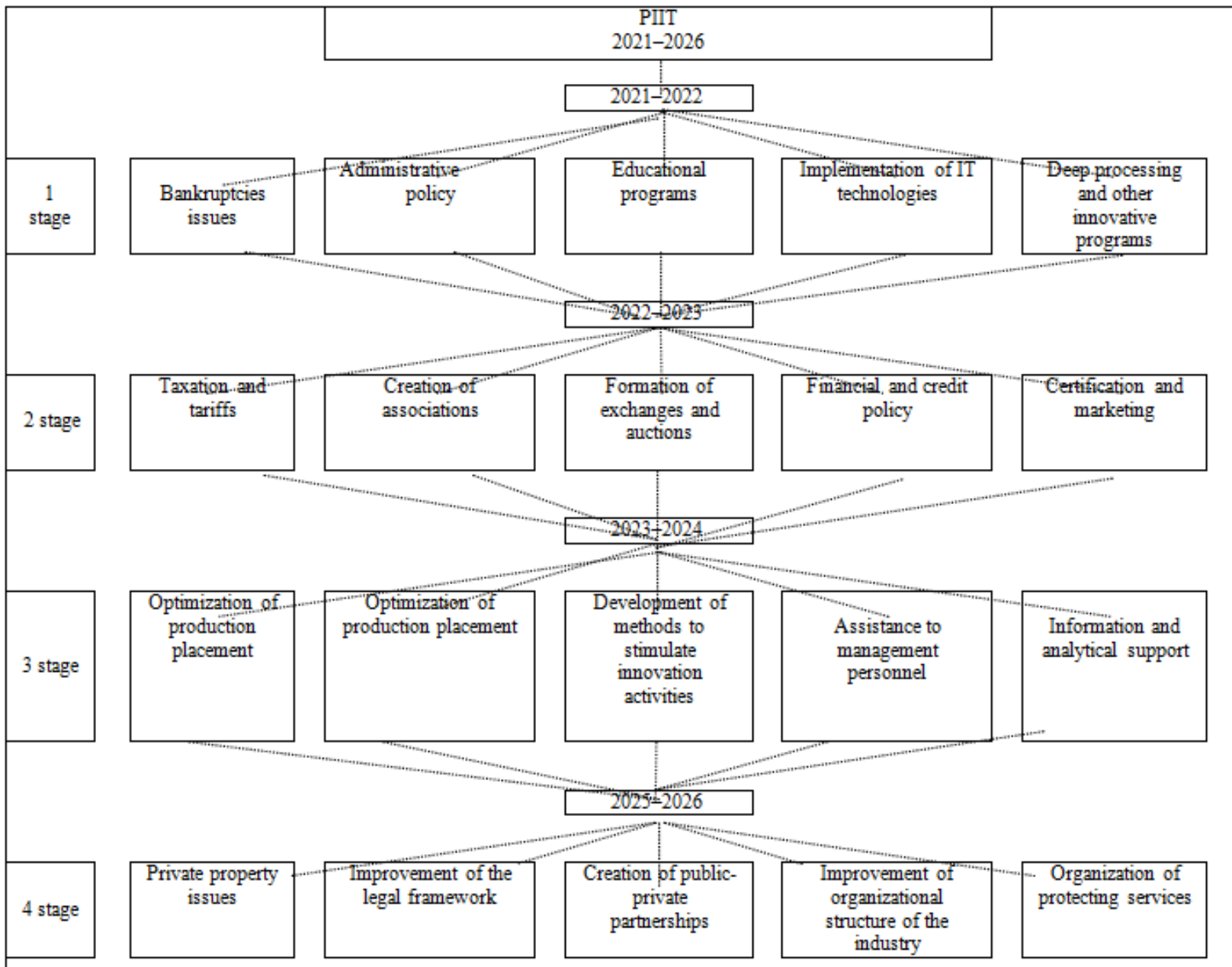

Fig. 1. Program of innovative and institutional transformations of the Forest industry.

The need for sustainable forest management becomes especially urgent in the context of the modern globalization of sales markets, the consolidation of forest business and growing economic, social, and environmental problems. This implies not only stable procurement of high-quality raw materials and their deep processing, but reproduction, conservation, and protection of forests too. Therefore, the main idea of sustainable forest management is to have a wellorganized forestry that functions without compromising the environment, economy, and forest users.

Sustainable development of the Forest industry involves, in particular, economic, ecological, and social sustainability. All these components are closely interrelated. Economic sustainability ensures social sustainability, and environmental-oriented forest management depends on economic and social stability. At the same time, excessive economic motivation to use of forests negatively affects the environmental situation, and high environmental requirements can threaten the social and economic stability of society. It is social sustainability that can serve as the indicator of the balance among the three dimensions of sustainability.

Based on the analysis of the industry, we propose the program of innovative and institutional transformations
(PIIT) of the Forest industry, which includes four consecutive stages, which are supposed to be implemented sequentially in time for the 5 years, and which has been partially realized (please, see figure 1).

\section{Conclusions}

The problems of the Forest industry are intersectoral, and theoretically interdisciplinary. The main requirement for the management of forests and the Forest industry is the organization of sustainable use of forest resources and utilities, which can only be achieved if the forest reproduction is at the level of constant scale. The transition to sustainable forest management involves the organization of multi-resource planning and forest management. The task is to develop an integrated system of measures, in which all individual forest resources that meet individual goals must be coordinated with each other to ensure the use of all resources in each individual section of the forest. This implies an integrated approach to forest management that ensures optimal and efficient use of forest resources. At the same time, it should be taken into account that the forest is not only an economic resource, but also an object of cultural heritage of the country. The organization and planning of multi- 
resource forest management is a priority for the implementation of the sustainable forest management program and will be included in the forestry economy. The sustainable and innovative use of forests is a promising direction for the development of the forest sector in Russia and its regions.

The organization of the Forest industry based on the principles of sustainable and multi-purpose forest management can be effective in the form of multi-level forest management. In this case, forest resources and products are divided into two groups: market resources that have a market value and public goods that are indivisible among individual consumers.

Thus, innovative development of the Forest industry, which can increase the efficiency and productivity, are not possible until institutional changes are introduced. The primary condition for the Forest industry transformation on the innovative basis is the formation of the Forest industry innovative system at the national level. The system which will be based on institutional innovations [8], accumulated efforts of the State, regional, and minicipal management bodies, of reserch and development organizations, and of entrepreneurs in the forest field, which is required to accelerate the implementation of science and technologies achievements to improve the quality of life of the population and provide sustainable economic development of Baikal region [7].

\section{References}

1. N. Biyanova, V. Barinov, $70 \%$ of the territory of Russia will be privatized, FLB.ru, Federal investigation Agency [Electronic resource] (in Russian) Available at: http://flb.ru/info/24780.htm

2. All about Russian forests [Electronic resource] Available at: http://www.forest.ru/rus/news/fires, http://www.forest.ru/rus/problems/news

3. N.Ya. Kalyuzhnova, Yu.V. Dolgov, M.I. Osipov, Institutional Economics: General course: textbook. manual (Irkutsk, Izd-vo IGU, 2012)

4. Forest code of the Russian Federation (Moscow, Prospect, KnoRus, 15 March 2012)

5. About specially protected natural territories: Feder. law, Collection of legislation of the Russian Federation, 33-FZ, 12, 1024 (14 March 1995)

6. The official website of the United Nations, Rio Declaration on environment and development [Electronic resource] Available at: http://www.un.org/ru/documents/decl_conv/decla rations/riodecl.shtml

7. A. Dayneko, D. Dayneko, V. Peshkov, M. Matveeva, Development of the regional innovation system in the Forest industry of Irkutsk province based on institutional changes, IOP Conference Series: Earth and Environmental Science DOI: 10.1088/1755-1315/316/1/012045

8. D.V. Dayneko, E.G. Gustafson, Institutional Innovations in the Forest Industry in Russia: A
Case Study Of Irkutsk Province, Miscellanea Geographica - Regional Studies on Development, Warsaw, Poland, 18 (4) (2014)

9. L. N. Vashchuk, L.V. Popov, N.M. Krasny, Forests and forestry of the Irkutsk province (Irkutsk, 1997, 288)

10. Fundamentals of the Russian Federation's policy in the field of science and technology development for the period up to 2010 and beyond, PR-576 [Electronic resource], Garant: reference and legal system (30 March 2002) Available at: http://base.garant.ru/12127915

11. D.V. Dayneko, A.P. Chernikov, Actual problems of development of the Forest industry of Irkutsk province [Electronic resource], Izvestiya Irkutsk State Economic Academy, 3 (2012) Available at: http://brj-bguep.ru/reader/article.aspx?id=13588. 